\title{
Review
}

\section{Calcium binding protein-mediated regulation of voltage-gated calcium channels linked to human diseases}

\author{
Nasrin NEJATBAKHSH, Zhong-ping FENG* \\ Department of Physiology, Faculty of Medicine, University of Toronto, 3306 MSB, 1 King's College Circle, Toronto, Ontario, Canada \\ M5S 1 A8
}

Calcium ion entry through voltage-gated calcium channels is essential for cellular signalling in a wide variety of cells and multiple physiological processes. Perturbations of voltage-gated calcium channel function can lead to pathophysiological consequences. Calcium binding proteins serve as calcium sensors and regulate the calcium channel properties via feedback mechanisms. This review highlights the current evidences of calcium binding protein-mediated channel regulation in human diseases.

Keywords: calcium binding proteins; voltage-gated calcium channels; EF-hand motif; calmodulin; calcium binding protein; calcineurin; calpain; visinin-like protein

Acta Pharmacologica Sinica (2011) 32: 741-748; doi: 10.1038/aps.2011.64

\section{Introduction}

Calcium $\left(\mathrm{Ca}^{2+}\right)$ entry via voltage-gated calcium channels (VGCCs), conveys the electric signals to intracellular transduction cascades in a wide variety of cells including neurons, muscle cells and endocrine cells ${ }^{[1]}$. $\mathrm{Ca}^{2+}$ dependent-signalling cascades are largely mediated by $\mathrm{Ca}^{2+}$ binding proteins ${ }^{[2,3]}$, and are essential for multiple cellular and subcellular processes in physiological conditions. Perturbations of VGCCs functions can cause abnormity of cellular events, leading to pathological consequences. $\mathrm{Ca}^{2+}$ binding proteins mediate $\mathrm{Ca}^{2+}$-dependent signal transduction pathways and regulate $\mathrm{Ca}^{2+}$ influx via the VGCCs in $\mathrm{Ca}^{2+}$-dependent feedback mechanisms.

VGCCs are classified into L-, N-, P/Q-, R-, and T-types, based on their distinct electrophysiological and pharmacological properties ${ }^{[4,5]}$. VGCCs are heteromultimeric protein complexes composed of a pore forming $\alpha_{1}$ and four distinct auxiliary subunits: $\alpha_{2}, \delta, \beta$, and $\gamma$ subunits ${ }^{[4-7]}$. Mammalian $\alpha_{1}$ subunits are encoded by at least 10 distinct genes ${ }^{[6,7]}$. The high voltage-activated VGCCs include $\mathrm{Ca}_{\mathrm{V}} 1$ and $\mathrm{Ca}_{\mathrm{V}} 2$ subfamilies. The $\mathrm{Ca}_{\mathrm{V}} 1$ subfamily $\left(\mathrm{Ca}_{\mathrm{V}} 1.1\right.$ to $\left.\mathrm{Ca}_{\mathrm{V}} 1.4\right)$ conducts L-type $\mathrm{Ca}^{2+}$ current and includes the channels containing $\mathrm{a}_{1 \mathrm{~S}}, \mathrm{a}_{1 \mathrm{C}}, \mathrm{a}_{1 \mathrm{D}}$, and $\mathrm{a}_{1 \mathrm{~F}}$ subunits. The $\mathrm{Ca}_{\mathrm{V}} 2$ subfamily $\left(\mathrm{Ca}_{\mathrm{V}} 2.1\right.$ to $\left.\mathrm{Ca}_{\mathrm{V}} 2.3\right)$ conducts $\mathrm{P} / \mathrm{Q}$-type, N-type, and R-type $\mathrm{Ca}^{2+}$ currents, through the chan-

\footnotetext{
* To whom correspondence should be addressed.

E-mail zp.feng@utoronto.ca

Received 2011-03-14 Accepted 2011-04-20
}

nels containing $\mathrm{a}_{1 \mathrm{~A}}, \mathrm{a}_{1 \mathrm{~B}}$, and $\mathrm{a}_{1 \mathrm{E}}$ subunits, respectively. The $\mathrm{Ca}_{\mathrm{V}} 3$ subfamily $\left(\mathrm{Ca}_{\mathrm{V}} 3.1\right.$ to $\left.\mathrm{Ca}_{\mathrm{V}} 3.3\right)$ conducts low voltage-activated T-type $\mathrm{Ca}^{2+}$ current mediated by the channels containing $a_{1 \mathrm{G}}, a_{1 \mathrm{H}}$, and $\mathrm{a}_{1 \mathrm{I}}$ subunits, respectively. The cell- and tissuespecific expression of these subunits allows for a vast variety of the channel subtypes exhibiting distinct functions.

$\mathrm{Ca}^{2+}$-binding proteins containing EF-hand $\mathrm{Ca}^{2+}$ binding motifs regulate mostly high voltage-activated $\mathrm{VGCCs}^{[8-12]}$. The EF-hand motif is a conserved $\mathrm{Ca}^{2+}$-binding structure, spanning a region of 30-35 amino acids containing a 12-residue $\mathrm{Ca}^{2+}$ binding loop flanked by the $\mathrm{N}$ - and C-terminal a-helix regions which are differentially exposed in the presence of $\mathrm{Ca}^{2+}[3,13,14]$. Each EF-hand protein has distinct $\mathrm{Ca}^{2+}$ binding affinity and cellular localization. The EF-hand $\mathrm{Ca}^{2+}$-binding protein superfamilies $^{[2,3,15]}$, such as calmodulin (CaM), calcineurin, calcium binding proteins $(\mathrm{CaBP})$, and neuronal $\mathrm{Ca}^{2+}$ sensors (NCSs), contains 2 to 4 functioning EF-hand $\mathrm{Ca}^{2+}$ binding domains. The EF-hand $\mathrm{Ca}^{2+}$-binding proteins may achieve their cellular effects through $\mathrm{Ca}^{2+}$-dependent or $\mathrm{Ca}^{2+}$-independent signalling mechanisms ${ }^{[16,17]}$ (Figure 1). Many EF-hand $\mathrm{Ca}^{2+}$-binding proteins alter $\mathrm{Ca}^{2+}$ kinetics directly through regulation of VGCC properties ${ }^{[8-12]}$. With the availability of human genetic databases and advanced molecular technologies, growing evidences suggest that dysfunctions in $\mathrm{Ca}^{2+}$-binding protein mediated VGCC regulation may be one of the mechanisms leading to human diseases. 


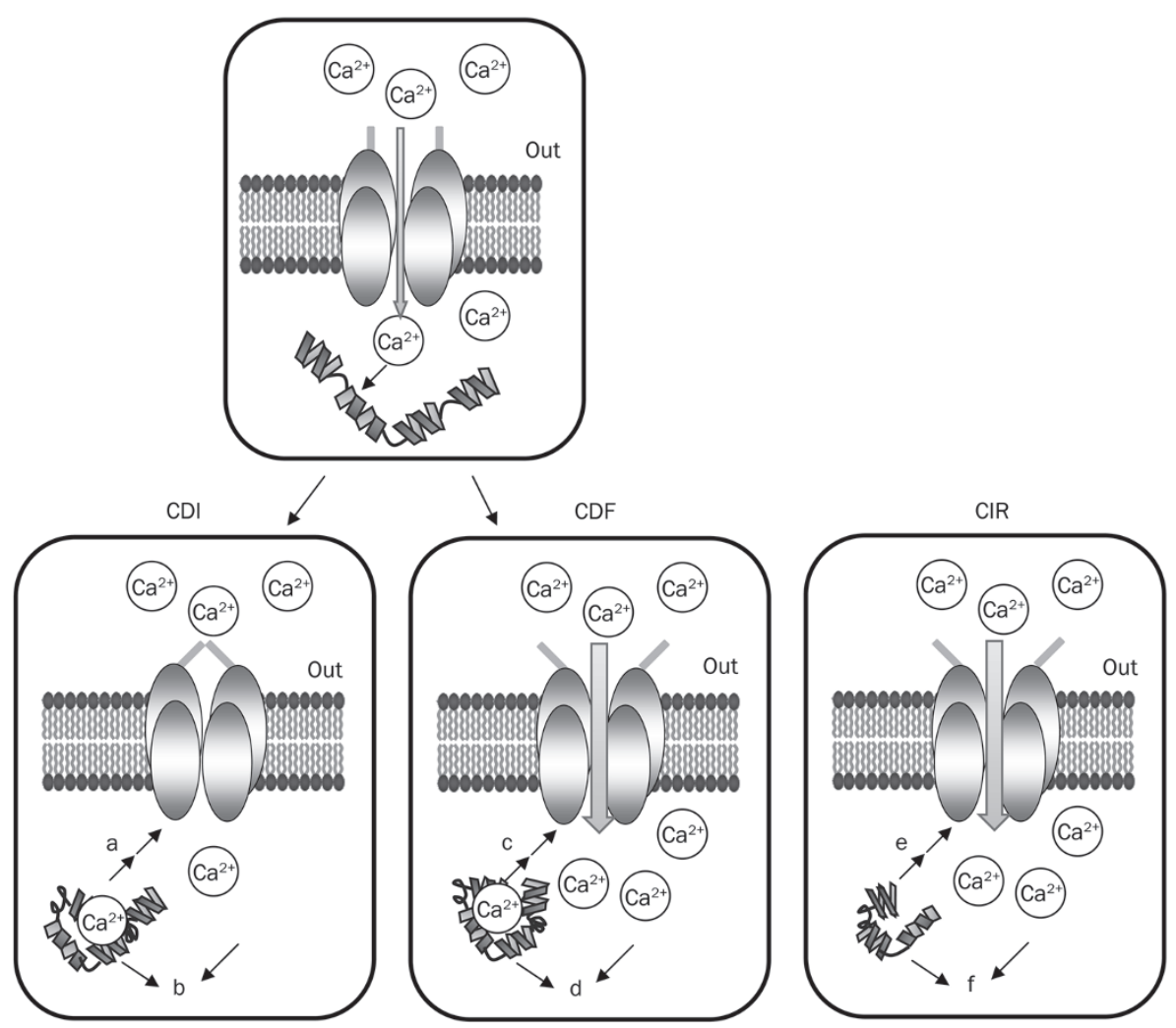

Figure 1. $\mathrm{Ca}^{2+}$ binding proteins regulate voltage-gated $\mathrm{Ca}^{2+}$ channels (VGCCs) via $\mathrm{Ca}^{2+}$ dependent inactivation (CDI), $\mathrm{Ca}^{2+}$-dependent facilitation (CDF) and $\mathrm{Ca}^{2+}$-independent regulation (CIR) of the channels, hence contributing to $\mathrm{Ca}^{2+}$ homeostasis. Disrupting $\mathrm{Ca}^{2+}$-binding protein-mediated VGCC regulation results in pathophysiological processes leading to human diseases. $\mathrm{CDI}: \mathrm{Ca}^{2+}$ ions entering the cell through VGCCs bind to $\mathrm{Ca}^{2+}$ binding proteins to (a) inactivate the channel via negative feedback mechanism, reducing further $\mathrm{Ca}^{2+}$ entry through the channel and (b) lead to downstream mechanisms and pathways implicated in human diseases. CDF: $\mathrm{Ca}^{2+}$ ions entering the cell through VGCCs bind to $\mathrm{Ca}^{2+}$ binding proteins to (c) facilitate the channel via a positive feedback mechanism, thus enhancing further $\mathrm{Ca}^{2+}$ entry through the channel and (d) lead to downstream mechanisms and pathways implicated in human diseases. CIR: $\mathrm{Ca}^{2+}$ binding proteins, in absence of $\mathrm{Ca}^{2+}$ binding (e) regulate VGCCs and (f) lead to downstream mechanisms and pathways implicated in human diseases.

\section{Calmodulin mediated $\mathrm{P} / \mathrm{Q}$-type regulation in familial hemiplegic migraine type 1}

The best studied $\mathrm{Ca}^{2+}$ binding protein that regulates VGCCs is $\mathrm{CaM}^{[18-20]}$. CaM contains 4 functional EF-hand motifs ${ }^{[21,22]}$, and regulates VGCCs properties in an enzymeinhibitor like fashion ${ }^{[23]}$. CaM binds to various high-voltage activated VGCCs and causes the $\mathrm{Ca}^{2+}$-dependent inactivation $(\mathrm{CDI})^{[8,9,24,25]}$ or $\mathrm{Ca}^{2+}$-dependent facilitation $(\mathrm{CDF})^{[10,12,26]}$ (Figure 1). In brief, CaM has a higher binding affinity to $\mathrm{Ca}^{2+}$ in the N-lobe than the C-lobe EF-hand motifs. This allows for antagonistic regulation of the $\mathrm{Ca}^{2+}$ channel through differential $\mathrm{Ca}^{2+}$ binding to $\mathrm{CaM}^{[27]}$. Specifically, CDI of $\mathrm{Ca}_{\mathrm{V}} 1.2$ channels ${ }^{[8,9,24]}$ and CDF of $\mathrm{Ca}_{\mathrm{v}} 2.1$ channels depend on $\mathrm{Ca}^{2+}$ binding to the C-lobe of $\mathrm{CaM}^{[10,27]}$. Conversely, $\mathrm{Ca}^{2+}$ binding to the N-lobe of CaM induces CDI of $\mathrm{Ca}_{\mathrm{v}} 2 \cdot 1^{[10,12,28]}, \mathrm{Ca}_{\mathrm{v}} 2 \cdot 2^{[10,12]}$, and Cav2. $3^{[10]}$ type channels. The differential regulatory effects of CaM on VGCCs are likely due to different conformational changes in the structure of $\mathrm{CaM}$ following $\mathrm{Ca}^{2+}$ binding at alternate sites. CaM-mediated regulation of the presynaptic VGCCs results in a dual feedback regulation. The cellular and molecular mechanisms underlying CaM mediated VGCC regulation have been extensively reviewed previously ${ }^{[18-20]}$.

FHM is characterized by recurrent migraines and includes visual disturbance, sensory loss, hemiparesis and ataxia. FHM type 1 is an autosomal dominant type of migraine with aura and hemiparesis, which is linked to the VGCC $\mathrm{a}_{1}$-subunit gene, $C A C N L 1 A 4$ encoding $\mathrm{Ca}_{\mathrm{V}} 2 \cdot 1^{[29-31]}$. All five FHM1 mutations change the biophysical properties of $\mathrm{Ca}_{\mathrm{v}} 2.1$ channels, leading to both gain and loss of P/Q-type channel function $^{[32,33]}$. Specifically, single channel recording showed that the mutations enhanced the open probability of the $\mathrm{Ca}_{\mathrm{v}} 2.1$ channels and shifted the activation gating of the channel to more negative voltages, allowing increased $\mathrm{Ca}^{2+}$ influx at more negative membrane potentials in cerebellar neurons ${ }^{[33,34]}$. Common treatments with $\mathrm{Ca}^{2+}$ channel blockers, such as verapamil, is effective in some FHM1 patients, carrying the CACNA1A mutations due to decreased open probability of P/Q-type $\mathrm{Ca}_{\mathrm{v}} 2.1$ channels and reduced $\mathrm{Ca}^{2+}$ influx ${ }^{[35]}$.

Consistent with reports of increased open-channel probability ${ }^{[22,33]}$, a recent study showed that FHM-1 missense mutants of the C-terminus in $\mathrm{Ca}_{\mathrm{v}} 2.1$ subunit, $\mathrm{R} 192 \mathrm{Q}$ and S218L, permitted a larger $\mathrm{Ca}^{2+}$ influx during action potentials than the wildtype channels in the cerebellar neurons ${ }^{[36]}$. Interestingly, these FHM-1 gain-of-function missense mutations characteristically occlude CDF of human $\mathrm{Ca}_{\mathrm{V}} 2.1$ channels in both recombinant preparations and the cerebellar Purkinje cells. The altered CDF of $\mathrm{Ca}_{\mathrm{v}} 2.1$ channels coincided with a decrease in short-term synaptic facilitation at the parallel fiberto-purkinje cell synapse in the cerebellum in FHM-1 mutant mice ${ }^{[36]}$. The compelling evidence suggests that FHM-1 gainof-function missense mutations of $\mathrm{Ca}_{\mathrm{v}} 2.1$ channels favour a constitutively facilitated state that prevents further $\mathrm{Ca}^{2+}$ dependent CaM-mediated channel facilitation. It is hypothesized that disruption of $\mathrm{Ca}_{\mathrm{V}} 2.1 \mathrm{CDF}$ may cause the cerebellar ataxia-associated FHM-1 due to an imbalance between excitatory and inhibitory inputs to the cerebellar Purkinje cells. This disruption suppresses the intrinsic pacemaker activity of these cells, thus leading to motor deficits ${ }^{[36]}$. The knock-in 
mouse model carrying FHM-1 R192Q mutation exhibited an enhanced velocity of cortical spreading depression in vivo ${ }^{[34]}$, and it is thus important to demonstrate whether the cortical hyper-excitability is also associated with perturbation of CDF of the mutant $\mathrm{Ca}_{\mathrm{v}} 2.1$ in future studies.

\section{CaBPs mediated L-type channel inactivation}

CaBPs consist of 8 members (CaBP 1-8) and are considered similar to $\mathrm{CaM}$ in that they bear four recognizable, but not necessarily functional EF-hands ${ }^{[37]}$. CaBP1, also known as caldendrin (a splice variant of $\mathrm{CaBP} 1)^{[38]}$, has $\sim 50 \%$ sequence homology to CaM and is widely expressed in the brain, including the cerebral cortex, hippocampus, in the cone bipolar and amacrine cells of the retina ${ }^{[39]}$, and in the inner hair cells. CaBP1 interacts with $\mathrm{Ca}_{\mathrm{v}} 2.1 \mathrm{P} / \mathrm{Q}$-type channels ${ }^{[40,41]}$, and L-type channels ${ }^{[42]}$. CaBP1 accelerates inactivation kinetics, prevents CaM-induced $\mathrm{Ca}_{\mathrm{V}} 2.1$ channel facilitation, and shifts the voltage-dependent activation of $\mathrm{Ca}_{\mathrm{v}} 2.1$ channels $^{[40]}$. These effects of $\mathrm{CaBP} 1$ are mediated by binding to the CaM-binding IQ-domain in the $\mathrm{a}_{1 \mathrm{~A}}$ subunit of $\mathrm{Ca}_{\mathrm{V}} 2.1$ channels. CaBP1 binding to the CaM binding domain (CBD) of $\mathrm{a}_{1 \mathrm{~A}}$ causes a significantly faster inactivation of $\mathrm{Ca}_{\mathrm{v}} 2.1$ channel than CaM.

CaBPs regulate L-type channels in a $\mathrm{Ca}^{2+}$-independent manner ${ }^{[40,42-44]}$ (Figure 1), in contrast to CaM. CaBP1 and $\mathrm{CaBP} 4$ act as negative regulators to compete with $\mathrm{CaM}$ binding to the C-terminal IQ motif in the $C a_{V} 1.2$ and $C a_{V} 1.3$ subunit ${ }^{[42,44-46]}$. CaBP1 also interacts with the N-terminal domain of $\mathrm{Ca}_{v} 1.2$ to prolong the channel activation, independent of CaM effect ${ }^{[42,44]}$. Some CaBPs, such as CaBP1 and $\mathrm{CaBP} 4$, have the capacity to negatively regulate influx of $\mathrm{Ca}^{2+}$ through a direct inhibitory interaction with plasma member $\mathrm{P} / \mathrm{Q}$-type channels in cochlear cells ${ }^{[45-47]}$. In the inner ear, at least $4 \mathrm{CaBPs}$ have been found in hair cells, including CaBP1, $\mathrm{CaBP} 2, \mathrm{CaBP} 4$ and CaBP5. Sustained activation of presynaptic $\mathrm{Ca}_{\mathrm{V}} 1.3$ channels triggers graded changes in neurotransmitter release which is required for sound detection ${ }^{[46]}$. CaBP1 binding to $\mathrm{Ca}_{\mathrm{v}} 1.3$ channels on $\mathrm{CaM}$ interaction sites, induced a stronger, than $\mathrm{CaBP} 4$, inhibition of $\mathrm{Ca}^{2+}$-dependent channel inactivation $^{[46]}$. Closely co-localization between CaBP1 and $\mathrm{Ca}_{\mathrm{V}} 1.3$ at the presynaptic ribbon synapse of adult inner hair cells further suggests CaBP1-mediated inhibitory effect on $\mathrm{Ca}^{2+}$-dependent inactivation of $\mathrm{Ca}_{\mathrm{v}} 1.3$ channel is critical for auditory transmission ${ }^{[46]}$.

$\mathrm{CaBP}^{[48]}$ and $\mathrm{CaBP}^{[49]}$ regulates L-type channels in photoreceptors. CaBP4 is located at the photoreceptor synaptic terminals in the retina, and is important for developing and sustaining synaptic transmission to bipolar cells ${ }^{[43]}$. CaBP4 regulates $\mathrm{Ca}_{\mathrm{V}} 1.4$ channel and shifts the activation of $\mathrm{Ca}_{\mathrm{V}} 1.4$ to more hyperpolarized potentials through a direct interaction with the C-terminal domain of the $\mathrm{Ca}_{v} 1.4$ channel protein. $\mathrm{CaBP}^{-/-}$mice exhibited visual deficits similar to that caused by dysfunction of $\mathrm{Ca}_{v} 1.4$ channels $^{[43,50,51]}$. CaBP4, like CaBP1, is found to interact with CaM-binding IQ domain in $\mathrm{Ca}_{v} 1.3$ to dampen the inactivation of the channel ${ }^{[40,46]}$. CaBP4 has the capacity to eliminate even the baseline $\mathrm{Ca}^{2+}$ dependent inactivation of $\mathrm{Ca}_{\mathrm{v}} 1.3^{[45]}$. Phosphorylation of S37 of CaBP4 by pro- tein kinase $C \zeta$ in retina regulates $C a_{v} 1.3$, likely by facilitating the low-affinity interaction which exerts inhibitory regulation of $\mathrm{Ca}_{\mathrm{V}} 1.3$ channel inactivation ${ }^{[48]}$. Phosphorylation of CaBP4 is critical for tuning presynaptic $\mathrm{Ca}^{2+}$ signals required for lightinduced neurotransmitter release. Incomplete congenital stationary night blindness (CSNB2) is linked to mutations in both $\mathrm{CaBP}^{452,53]}$ and $\mathrm{Ca}_{\mathrm{V}} 1.4^{[54-56]}$. Interrelation between CaBP4 and $\mathrm{Ca}_{\mathrm{V}} 1.4$ in CSNB2 remains to be determined.

\section{Bestrophin-1 mediated $\mathrm{Ca}_{\mathbf{v}} \mathbf{1 . 3}$ modulation in macular degeneration}

Bestrophins are a family of calcium-activated chloride channels ${ }^{[57]}$ encoded with VMD2 (Best vitelliform macular dystrophy-2) gene on chromosome $11 \mathrm{q} 13^{[58]}$. Human bestrophin-1 (hBest1) is a founding member of the family and contains one EF-hand (EF1, 350-390) at the C-terminal and a regulatory domain adjacent to EF1 that is required for $\mathrm{Ca}^{2+}$ activation of the channel ${ }^{[59]}$. EF1 has a slightly higher $\mathrm{Ca}^{2+}$-binding affinity than the third EF hand of CaM and lower affinity than the second EF hand of troponin C. Mutations in hBest1 are involved in $\sim 100$ human diseases ${ }^{[58]}$.

Retinal cell death, induced by glaucoma, diabetic reinopathy and age-related macular degeneration are primarily caused by a form of metabolic stress which results from a lack of nutrient supply. This process is initiated primarily through the activation of NMDA receptors with a subsequent influx of $\mathrm{Ca}^{2+}$ and $\mathrm{Na}^{+}$ions into the cells ${ }^{[60]}$. The close relationship between ataxia and macular degeneration suggests that these disorders may share a common molecular network ${ }^{[6]]}$. Oxidative stress, an important cause of retinal pigmental eipithelium death and subsequent age-related macular degeneration, induces calcium overload and leads to cell injury ${ }^{[62]}$. Oxidative stress induced elevation of $\mathrm{Ca}^{2+}$ level is sensitive to VGCC blocker ${ }^{[62]}$, suggesting the role of VGCCs in retinal cell death.

The hBest1 is localized at the basolateral plasma membrane of the retinal pigment epithelium cells ${ }^{[63]}$. Mutations of the hBest1 gene are associated with macular degeneration ${ }^{[58]}$. Bestrophin-1 is co-localized with $\mathrm{Ca}_{\mathrm{v}} 1.3$ channels and the auxiliary $\beta 4$-subunit in the cell membrane in the retinal pigment epithelium, and inhibits $\mathrm{Ca}_{\mathrm{V}} 1.3$ channels via a direct interaction with the $\mathrm{Ca}_{v} \beta 4$ subunit ${ }^{[64,65]}$. Mutations of hBest1 on P330 and P334 prevented Best1-mediated inhibition of $\mathrm{Ca}_{\mathrm{V}} 1.3^{[64,65]}$. These findings provide new insights into the mechanisms of the retinal degeneration involved in hBest1-mediated $\mathrm{Ca}_{\mathrm{V}} 1.3$ channel regulation.

\section{Calcineurin regulation of $\mathrm{Ca}^{2+}$ channels in human diseases}

Calcineurin is a calcium-dependent phosphatase activated by $\mathrm{Ca}^{2+} / \mathrm{CaM}^{[66]}$. It is a heterodimer and consisted of a 59 $\mathrm{kDa}$ catalytic subunit and a $19 \mathrm{kDa} \mathrm{Ca}{ }^{2+}$-binding regulatory subunit. Calcineurin regulatory subunit is encoded with four putative EF-hand $\mathrm{Ca}^{2+}$-binding motifs ${ }^{[33]}$. The high-affinity $\mathrm{Ca}^{2+}$ binding site has a $K_{\mathrm{d}}$ of $\sim 24 \mathrm{nmol} / \mathrm{L}$ to $\mathrm{Ca}^{2+}$ whereas three low-affinity binding sites have a $K_{\mathrm{d}}$ of $15 \mu \mathrm{mol} / \mathrm{L}$ to $\mathrm{Ca}^{2+[33]}$. Calcineurin regulates L-type channels in both myocytes ${ }^{[67]}$ and 
neurons ${ }^{[68,69]}$.

Calcineurin regulation of $\mathrm{Ca}_{\mathrm{v}} 1.2$ L-type channel in cardiac hypertrophy

$\mathrm{Ca}^{2+}$ signalling pathways play a critical role in the development of cardiac hypertrophy, one of the predisposing factors related to hypertension and development of heart failure. The downstream effector of calcineurin, NFAT signalling transduction pathway, plays a critical role in pathological cardiac hypertrophy response ${ }^{[70,71]}$. L-type $\mathrm{Ca}_{\mathrm{V}} 1.2$ channels play an important role in blood pressure and development of myogenic tone. In cardiac muscles, L-type currents through $\mathrm{Ca}_{\mathrm{V}} 1.2$ channels stimulate the excitation-contraction coupling. The C-terminus of this channel serves an autoinhibitory role to mediate the fight-or-flight response. Inactivation of $\mathrm{Ca}_{\mathrm{V}} 1.2$ was found to reduce mean arterial blood pressure in mice and there was a severe dampening of response to penylephrine and angiotensin II, due to a significant portion of penylephrine-induced resistance being dependent on calcium influx through the $\mathrm{Ca}_{\mathrm{V}} 1.2$ channel $^{[72]}$. The truncation in the distal C-terminus of the $\mathrm{a}_{1}$ subunit of $\mathrm{Ca}_{\mathrm{V}} 1.2$ leads to $10-15$ fold increase in channel activity in mammalian cell lines $^{[73]}$. The increased force of contraction during the fightor-flight response is thought to be mediated by regulation of $\mathrm{Ca}_{\mathrm{V}} 1.2$ channels via activation of secondary systems which act to phosphorylate the channel ${ }^{[74]}$. Deletion of this C-terminus causes a reduction in $\mathrm{Ca}^{2+}$ currents, as a result of lower surface expression of the channel, and leads to development of cardiac hypertrophy and premature death after E15 during embryonic development in mice ${ }^{[25]}$.

Recently, an EF-hand containing $\mathrm{Ca}^{2+}$ and integrin-binding protein-1 (CIB1) was found to specifically enhance cardiac pathological hypertrophy, without a role in altering physiological hypertrophy, through a regulation of calcineurin interaction with the sarcolemma ${ }^{[75]}$. One mechanism of calcineurin function is thought to be via L-type channels, which mediates $\mathrm{Ca}^{2+}$ influx into cardiomyocytes. Transgenic mice expressing an activated form of calcineurin were found to exhibit an enhanced $I_{\mathrm{Ca}}$ density compared with the non-transgenic littermates and to have a faster kinetics of $I_{\mathrm{Ca}}$ inactivation ${ }^{[67]}$. Calcineurin can directly bind to both N- and C-termini (a.a. 1943-1971) of $\mathrm{Ca}_{\mathrm{V}} 1.2$ channels, and dephosphorylate the channels, which in turn increase the channel conductance ${ }^{[76]}$. Magnesium ions $\left(\mathrm{Mg}^{2+}\right)$ bind to the C-terminal EF-hand to inhibit $\mathrm{Ca}_{\mathrm{V}} 1.2$ channels, thereby reducing $\mathrm{Ca}^{2+}$ influx to maintain the intracellular $\mathrm{Ca}^{2+}$ at low levels ${ }^{[77]}$. Supplement of $\mathrm{Mg}^{2+}$ during global ischemia resulted in myocardial protection and improved functional recovery ${ }^{[78]}$. These evidences suggest that calcineurin serves as a key modulator of $\mathrm{Ca}^{2+}$-dependent pathways via regulation of $\mathrm{Ca}_{\mathrm{V}} 1.2$ activities and in turn mediates the pathological electrical remodelling in cardiac hypertrophy.

\section{Calcineurin regulation of L-type channels in neurodegenerative} diseases

Calcineurin selectively enhances L-type channel activity in hippocampal neurons ${ }^{[68,69]}$. Application of FK506, an inhibitor of calcineurin, reduces high-voltage-activated $\mathrm{Ca}^{2+}$ current via L-type, but not $\mathrm{P} / \mathrm{Q}$ - or N-type channels ${ }^{[68]}$. PKA and calcineurin bind to A-kinase anchoring protein 79/150 (AKAP79/150), which interact with endogenous and recombinant $\mathrm{Ca}_{\mathrm{V}} 1.2$ channels in hippocampal neurons and HEK293 cells, respectively ${ }^{[66]}$. Disruption of AKAP79/150calcineurin anchoring increases $\mathrm{Ca}^{2+}$ current amplitude ${ }^{[66]}$. In contrast to $\mathrm{CaM}$, calcineurin does not affect $\mathrm{Ca}^{2+}$-dependent inactivation of the neuronal L- or N-type channels; this conclusion is based on the findings that FK506 has no effect on the time-course of $\mathrm{Ca}^{2+}$ current inactivation of L-type channel in rat pituitary tumor cell line (GH3) and N-type channels in chicken dorsal root ganglion neurons, while $\mathrm{Ca}^{2+}$-dependent inactivation of the channels is prevented by $\mathrm{Ca}^{2+}$ chelator EGTA $^{[79]}$. Calcineurin promotes dephosphorylation of $3^{\prime}$, $5^{\prime}$-cyclic AMP response element binding protein $(\mathrm{CREB})^{[29]}$. Overexpression of calcineurin prevents ${ }^{[30]}$ and inhibition of calcineurin enhances long-term memory formation ${ }^{[31,80]}$. The activity of calcineurin increases in the hippocampus during aging, and L-type channel block reduces calcineurin activity ${ }^{[81]}$. Cleavage of calcineurin by $\mathrm{Ca}^{2+}$-sensitive protease calpain ${ }^{[82]}$ enhances its phosphatase activity, which coincides with an increase in the number of neurofibrillary tangles in human brains of patients with Alzheimer's disease ${ }^{[83]}$. Interestingly, amyloid- $\beta$ protein also increases the activity of calcineurin, leading to dephosphorylation of the proapototic protein BAD (Bcl-2/Bcl- $\mathrm{X}_{\mathrm{L}}$-antagonist) causing cell death ${ }^{[84]}$ and subsequent activation of apoptotic pathways in Alzheimer's disease ${ }^{[85]}$. Calcineurin activity is implicated in age-related $\mathrm{Ca}^{2+}$ dysregulation in neurodegenerative disorders ${ }^{[69]}$. However, the role of EF-hand motifs in calcineurin-enhanced L-type channel activation, and the causal relation between calcineurin and VGCC regulation in degenerative disorders remain to be further investigated.

\section{Perspectives and future directions}

Functional diversity within related $\mathrm{Ca}^{2+}$-binding proteins may enhance the specificity of $\mathrm{Ca}^{2+}$ signalling by VGCCs in different cellular contexts. These channels undergo feedback mechanisms by $\mathrm{Ca}^{2+}$-dependent facilitation or inactivation. Such feedback is largely mediated by $\mathrm{Ca}^{2+}$ binding proteins. Increasing evidences demonstrate that the diverse and integrative roles of the abundant calcium binding proteins in VGCC regulation and $\mathrm{Ca}^{2+}$ signalling may be attributed to human diseases. However, our understanding of the role of such regulation in human diseases is rather limited, due to the complexity of the intracellular protein networks in which integrative functions of $\mathrm{Ca}^{2+}$ binding proteins must alter continuously to fit to the dynamic changes of $\mathrm{Ca}^{2+}$ signalling.

Many $\mathrm{Ca}^{2+}$ binding proteins have been found to regulate VGCCs, however, little is known about how such regulations are related to the pathophysiological processes. For instance, neuronal $\mathrm{Ca}^{2+}$ sensor-1/frequenin-1 (NCS-1/frq1) containing three functional EF-hand $\mathrm{Ca}^{2+}$ binding motifs ${ }^{[15,86-88]}$ exhibits a 10 fold higher affinity for $\mathrm{Ca}^{2+}$ than $\mathrm{CaM}^{[89]}$. NCS-1 is highly localized at the presynaptic terminal of the vertebrates ${ }^{[90-95]}$ and 
invertebrates ${ }^{[88,96-98]}$, and facilitates synaptic transmission. It increases the P/Q-type $\mathrm{Ca}^{2+}$ current in the Calyx of Held of the giant presynaptic terminal ${ }^{[90]}$, and regulates the presynaptic N-type channels in motoneurons ${ }^{[99]}$ and growth cone VGCCs in Lymnaea neurons ${ }^{[100,101]}$. Another example is visinin-like protein-2 (VILIP-2), a highly homologous subfamily of NCS proteins and capable of undergoing $\mathrm{Ca}^{2+}$-myristoyl switch ${ }^{[102,103]}$. VILIP-2 slows inactivation ${ }^{[104]}$ and enhances facilitation ${ }^{[105]}$ of the presynaptic $\mathrm{P} / \mathrm{Q}$-type $\mathrm{Ca}^{2+}$ channels, by a direct interaction with the CBD of the C-terminus of $\mathrm{Ca}_{\mathrm{V}} 2.1$. However, whether and how NCS-1 or VILIP-2-mediated VGCC regulation contributes to human diseases remain unclear. Conversely, down-regulation of VILIP-1 has been reported in several types of human cancers ${ }^{[106,107]}$, and in heart failure/cardiac hypertrophy ${ }^{[108]}$. However, whether VILIP-1 effect is associated with VGCC regulation is unknown. Thus, it is necessary to further investigate if there is interrelation between VGCC regulation by $\mathrm{Ca}^{2+}$ binding proteins and human diseases.

Dysregulation of $\mathrm{Ca}^{2+}$ homeostasis leads to pathophysiological processes related to human diseases. For instance, a disruption of basal and stimulus-dependent $\mathrm{Ca}^{2+}$ levels has been reported in brains of patients suffering from Alzheimer's disease ${ }^{[109]}$. The level of $\mathrm{Ca}^{2+}$-sensitive protease calpain-1 in the prefrontal cortex is 3-fold higher in the postmorten brains of individuals with Alzheimer's disease, than those with other neurodegenerative disorders, such as Huntington's or Parkinson's disease. Calpain- 1 activates $\mathrm{Ca}^{2+}$-sensitive phosphatase calcineurin by cleaving lysine501 at the C-terminal ${ }^{[83]}$. The abnormally enhanced calpain and truncated calcineurin activities correlate with the level of secreted amyloid precursor protein and progression of Alzheimer's disease ${ }^{[110,111]}$. Thus, disruption of $\mathrm{Ca}^{2+}$ homeostasis in neuropathology of Alzheimer's disease may be mediated by hyperactivity of calpain-1 and calcineurin. Similarly, a-synuclein, a key protein in the pathophysiology of Parkinson's disease ${ }^{[112,113]}$, binds to calmodulin in a $\mathrm{Ca}^{2+}$-dependent manner ${ }^{[114]}$. a-Synucleincalmodulin interaction accelerates fibrilization of synuclein, crucial for forming the core of Lewy bodies. a-Synuclein also colocalizes with other $\mathrm{Ca}^{2+}$-binding proteins, including calbindin and parvalbumin ${ }^{[115]}$, implicating the significance of $\mathrm{Ca}^{2+}$-dependent signalling in the development of Parkinson's disease. One implication of these findings is that a tight regulation of $\mathrm{Ca}^{2+}$ homeostasis by $\mathrm{Ca}^{2+} / \mathrm{Ca}^{2+}$-sensitive proteins serves as a compelling mechanism for pathophysiological processes in neurodegenerative and/or cardiovascular disorders. Understanding such mechanisms allows us to identify potential drug targets for delaying or prevention of the onset of the related human diseases. However, this line of research is still at its infancy, and deserves further attention. With current advancement in genetic and epigenetic sequencing techniques and increased availability of the gene and protein databases of human diseases, exploring the role of $\mathrm{Ca}^{2+}$ binding proteins in VGCC regulation and their involvement in human diseases are becoming feasible in future studies.

\section{Acknowledgements}

This work was supported by an operating grant to ZPF from the Canadian Institutes of Health Research (CIHR MOP62738). $\mathrm{NN}$ is the recipient of an NSERC CGS-PhD studentship. ZPF holds a New Investigator Award from the Heart and Stroke Foundation of Canada.

\section{References}

1 Spitzer NC. Calcium: first messenger. Nat Neurosci 2008; 11: 2434.

2 Schaub MC, Heizmann CW. Calcium, troponin, calmodulin, S100 proteins: from myocardial basics to new therapeutic strategies. Biochem Biophys Res Commun 2008; 369: 247-64.

3 Yap KL, Ames JB, Swindells MB, Ikura M. Diversity of conformational states and changes within the EF-hand protein superfamily. Proteins 1999; 37: 499-507.

4 Stea A, Soong TW, Snutch TP. Voltage-gated calcium channels in ligand- and voltage-gated ion channels (ed North, RA). Boca Raton (FL): CRC Press; 1995. p113-141.

5 Catterall WA. Structure and regulation of voltage-gated $\mathrm{Ca}^{2+}$ channels. Annu Rev Cell Dev Biol 2000; 16: 521-55.

6 Catterall WA, Perez-Reyes E, Snutch TP, Striessnig J. International Union of Pharmacology. XLVIII. Nomenclature and structure-function relationships of voltage-gated calcium channels. Pharmacol Rev 2005; 57: 411-25.

7 Dolphin AC. Calcium channel diversity: multiple roles of calcium channel subunits. Curr Opin Neurobiol 2009; 19: 237-44.

8 Zuhlke RD, Pitt GS, Tsien RW, Reuter H. $\mathrm{Ca}^{2+}$-sensitive inactivation and facilitation of L-type $\mathrm{Ca}^{2+}$ channels both depend on specific amino acid residues in a consensus calmodulin-binding motif in the(alpha)1C subunit. J Biol Chem 2000; 275: 21121-9.

9 Pitt GS, Zuhlke RD, Hudmon A, Schulman H, Reuter H, Tsien RW. Molecular basis of calmodulin tethering and $\mathrm{Ca}^{2+}$-dependent inactivation of L-type $\mathrm{Ca}^{2+}$ channels. J Biol Chem 2001; 276: 30794-802.

10 Liang H, DeMaria CD, Erickson MG, Mori MX, Alseikhan BA, Yue DT. Unified mechanisms of $\mathrm{Ca}^{2+}$ regulation across the $\mathrm{Ca}^{2+}$ channel family. Neuron 2003; 39: 951-60.

11 Lee A, Catterall WA. $\mathrm{Ca}^{2+}$-dependent modulation of voltage-gated $\mathrm{Ca}^{2+}$ channels in voltage-gated calcium channels (ed Gerald Zamponi). Texas (USA): Landes Bioscience; 2005. p183-193.

12 Dick IE, Tadross MR, Liang H, Tay LH, Yang W, Yue DT. A modular switch for spatial $\mathrm{Ca}^{2+}$ selectivity in the calmodulin regulation of $\mathrm{CaV}$ channels. Nature 2008; 451: 830-4.

13 Kretsinger RH, NockoldsCE. Carp muscle calcium-binding protein. II. Structure determination and general description. J Biol Chem 1973; 248: 3313-26.

14 Gariepy J, Hodges RS. Primary sequence analysis and folding behavior of $\mathrm{EF}$ hands in relation to the mechanism of action of troponin C and calmodulin. FEBS Lett 1983; 160: 1-6.

15 Burgoyne RD, Weiss JL. The neuronal calcium sensor family of $\mathrm{Ca}^{2+}$ binding proteins. Biochem J 2001; 353: 1-12.

16 Burgoyne RD, O'Callaghan DW, Hasdemir B, Haynes LP, Tepikin AV. Neuronal $\mathrm{Ca}^{2+}$-sensor proteins: multitalented regulators of neuronal function. Trends Neurosci 2004; 27: 203-9.

17 Burgoyne RD. Neuronal calcium sensor proteins: generating diversity in neuronal $\mathrm{Ca}^{2+}$ signalling. Nat Rev Neurosci 2007; 8: 182-93.

18 Halling DB, Racena-Parks P, Hamilton SL. Regulation of voltagegated $\mathrm{Ca}^{2+}$ channels by calmodulin. Sci STKE 2006; er1.

19 Zamponi GW. Calmodulin lobotomized: novel insights into calcium regulation of voltage-gated calcium channels. Neuron 2003; 39: 
879-81.

20 Catterall WA, Few AP. Calcium channel regulation and presynaptic plasticity. Neuron 2008; 59: 882-901.

21 Dalgarno DC, Klevit RE, Levine BA, Williams RJ, Dobrowolski Z, Drabikowski W. ${ }^{1} \mathrm{H}$ NMR studies of calmodulin. Resonance assignments by use of tryptic fragments. Eur J Biochem 1984; 138: 2819.

22 Klevit RE, Dalgarno DC, Levine BA, Williams RJ. ${ }^{1} \mathrm{H}-\mathrm{NMR}$ studies of calmodulin. The nature of the $\mathrm{Ca}^{2+}$-dependent conformational change. Eur J Biochem 1984; 139: 109-14.

23 Liu X, Yang PS, Yang W, Yue DT. Enzyme-inhibitor-like tuning of $\mathrm{Ca}^{2+}$ channel connectivity with calmodulin. Nature 2010; 463: 968-72.

24 Mori MX, Erickson MG, Yue DT. Functional stoichiometry and local enrichment of calmodulin interacting with $\mathrm{Ca}^{2+}$ channels. Science 2004; 304: 432-5.

25 Fu Y, Westenbroek RE, Yu FH, Clark JP III, Marshall MR, Scheuer T, et al. Deletion of the distal C-terminus of Cav1.2 channel leads to loss of beta-adrenergic regulation and heart failure in vivo. J Biol Chem 2011;

26 DeMaria CD, Soong TW, Alseikhan BA, Alvania RS, Yue DT. Calmodulin bifurcates the local $\mathrm{Ca}^{2+}$ signal that modulates $\mathrm{P} / \mathrm{Q}$-type $\mathrm{Ca}^{2+}$ channels. Nature 2001; 411: 484-9.

27 Erickson MG, Alseikhan BA, Peterson BZ, Yue DT. Preassociation of calmodulin with voltage-gated $\mathrm{Ca}^{2+}$ channels revealed by FRET in single living cells. Neuron 2001; 31: 973-85.

28 Lee A, Zhou H, Scheuer T, Catterall WA. Molecular determinants of $\mathrm{Ca}^{2+} /$ calmodulin-dependent regulation of $\mathrm{Ca}(\mathrm{v}) 2.1$ channels. Proc Natl Acad Sci U S A 2003; 100: 16059-64.

29 Pietrobon D. Familial hemiplegic migraine. Neurotherapeutics 2007; 4: 274-84.

30 Pietrobon D. Insights into migraine mechanisms and CaV2.1 calcium channel function from mouse models of familial hemiplegic migraine. J Physiol 2010; 588: 1871-8.

31 Ophoff RA, Terwindt GM, Vergouwe MN, van ER, Oefner PJ, Hoffman $\mathrm{SM}$, et al. Familial hemiplegic migraine and episodic ataxia type-2 are caused by mutations in the $\mathrm{Ca}^{2+}$ channel gene CACNL1A4. Cell 1996; 87: 543-52.

32 Hans M, Luvisetto S, Williams ME, Spagnolo M, Urrutia A, Tottene A et al. Functional consequences of mutations in the human alpha1A calcium channel subunit linked to familial hemiplegic migraine. J Neurosci 1999; 19: 1610-9.

33 Tottene A, Fellin T, Pagnutti S, Luvisetto S, Striessnig J, Fletcher C, et al. Familial hemiplegic migraine mutations increase $\mathrm{Ca}^{2+}$ influx through single human CaV2.1 channels and decrease maximal CaV2.1 current density in neurons. Proc Natl Acad Sci U S A 2002; 99: 13284-9.

34 van den Maagdenberg AM, Pietrobon D, Pizzorusso T, Kaja S, Broos LA, Cesetti T, et al. A Cacna1a knockin migraine mouse model with increased susceptibility to cortical spreading depression. Neuron 2004; 41: 701-10.

35 Knierim E, Leisle L, Wagner C, Weschke B, Lucke B, Bohner G, et al. Recurrent stroke due to a novel voltage sensor mutation in Cav2.1 responds to verapamil. Stroke 2011; 42: e14-7.

36 Adams PJ, Rungta RL, Garcia E, van den Maagdenberg AM, MacVicar BA, Snutch TP. Contribution of calcium-dependent facilitation to synaptic plasticity revealed by migraine mutations in the P/Q-type calcium channel. Proc Natl Acad Sci U S A 2010; 107: 18694-9.

37 Haeseleer F, Palczewski K. Calmodulin and $\mathrm{Ca}^{2+}$-binding proteins (CaBPs): variations on a theme. Adv Exp Med Biol 2002; 514: 30317.

38 Laube G, Seidenbecher Cl, Richter K, Dieterich DC, Hoffmann
$\mathrm{B}$, Landwehr $\mathrm{M}$, et al. The neuron-specific $\mathrm{Ca}^{2+}$-binding protein caldendrin: gene structure, splice isoforms, and expression in the rat central nervous system. Mol Cell Neurosci 2002; 19: 459-75.

39 Haeseleer F, Sokal I, Verlinde CL, Erdjument-Bromage H, Tempst P, Pronin AN, et al. Five members of a novel $\mathrm{Ca}^{2+}$-binding protein (CABP) subfamily with similarity to calmodulin. J Biol Chem 2000; 275: 1247-60.

40 Lee A, Westenbroek RE, Haeseleer F, Palczewski K, Scheuer T, Catterall WA. Differential modulation of $\mathrm{Ca}(\mathrm{v}) 2.1$ channels by calmodulin and $\mathrm{Ca}^{2+}$-binding protein 1. Nat Neurosci 2002; 5: 210-7.

41 Haynes LP, Tepikin AV, Burgoyne RD. Calcium-binding protein 1 is an inhibitor of agonist-evoked, inositol 1,4,5-trisphosphate-mediated calcium signaling. J Biol Chem 2004; 279: 547-55.

42 Zhou H, Yu K, McCoy KL, Lee A. Molecular mechanism for divergent regulation of Cav1.2 $\mathrm{Ca}^{2+}$ channels by calmodulin and $\mathrm{Ca}^{2+}$-binding protein-1. J Biol Chem 2005; 280: 29612-9.

43 Haeseleer F, Imanishi Y, Maeda T, Possin DE, Maeda A, Lee A, et al. Essential role of $\mathrm{Ca}^{2+}$-binding protein 4, a Cav1.4 channel regulator, in photoreceptor synaptic function. Nat Neurosci 2004; 7: 1079-87.

44 Zhou H, Kim SA, Kirk EA, Tippens AL, Sun H, Haeseleer F, et al. $\mathrm{Ca}^{2+}$ binding protein-1 facilitates and forms a postsynaptic complex with Cav1.2 (L-type) $\mathrm{Ca}^{2+}$ channels. J Neurosci 2004; 24: 4698-708.

45 Yang PS, Alseikhan BA, Hiel H, Grant L, Mori MX, Yang W, et al. Switching of $\mathrm{Ca}^{2+}$-dependent inactivation of $\mathrm{Ca}(\mathrm{v}) 1.3$ channels by calcium binding proteins of auditory hair cells. J Neurosci 2006; 26 : 10677-89.

46 Cui G, Meyer AC, Calin-Jageman I, Neef J, Haeseleer F, Moser T, et al. $\mathrm{Ca}^{2+}$-binding proteins tune $\mathrm{Ca}^{2+}$-feedback to Cav1.3 channels in mouse auditory hair cells. J Physiol 2007; 585: 791-803.

47 Lee S, Briklin O, Hiel H, Fuchs P. Calcium-dependent inactivation of calcium channels in cochlear hair cells of the chicken. J Physiol 2007; 583: 909-22.

48 Lee A, Jimenez A, Cui G, Haeseleer F. Phosphorylation of the $\mathrm{Ca}^{2+}$ binding protein $\mathrm{CaBP} 4$ by protein kinase $\mathrm{C}$ zeta in photoreceptors. J Neurosci 2007; 27: 12743-54.

49 Rieke F, Lee A, Haeseleer F. Characterization of $\mathrm{Ca}^{2+}$-binding protein 5 knockout mouse retina. Invest Ophthalmol Vis Sci 2008; 49: 5126-35.

50 Mansergh F, Orton NC, Vessey JP, Lalonde MR, Stell WK, Tremblay $F$, et al. Mutation of the calcium channel gene Cacna1f disrupts calcium signaling, synaptic transmission and cellular organization in mouse retina. Hum Mol Genet 2005; 14: 3035-46.

51 Chang B, Heckenlively JR, Bayley PR, Brecha NC, Davisson MT, Hawes NL, et al. The nob2 mouse, a null mutation in Cacna1f: anatomical and functional abnormalities in the outer retina and their consequences on ganglion cell visual responses. Vis Neurosci 2006; 23: 11-24.

52 Zeitz C, Labs S, Lorenz B, Forster U, Uksti J, Kroes HY, et al. Genotyping microarray for CSNB-associated genes. Invest Ophthalmol Vis Sci 2009; 50: 5919-26.

53 Zeitz C, Kloeckener-Gruissem B, Forster U, Kohl S, Magyar I, Wissinger $\mathrm{B}$, et al. Mutations in CABP4, the gene encoding the $\mathrm{Ca}^{2+}$-binding protein 4, cause autosomal recessive night blindness. Am J Hum Genet 2006; 79: 657-67.

54 Lodha N, Bonfield S, Orton NC, Doering CJ, McRory JE, Mema SC et al. Congenital stationary night blindness in mice - a tale of two cacna1f mutants. Adv Exp Med Biol 2010; 664: 549-58.

55 Strom TM, Nyakatura G, pfelstedt-Sylla E, Hellebrand H, Lorenz $\mathrm{B}$, Weber $\mathrm{BH}$, et al. An L-type calcium-channel gene mutated in incomplete X-linked congenital stationary night blindness. Nat Genet 1998; 19: 260-3. 
56 Hoda JC, Zaghetto F, Koschak A, Striessnig J. Congenital stationary night blindness type 2 mutations S229P, G369D, L1068P, and W1440X alter channel gating or functional expression of $\mathrm{Ca}(\mathrm{v}) 1.4$ L-type $\mathrm{Ca}^{2+}$ channels. J Neurosci 2005; 25: 252-9.

57 Kunzelmann K, Milenkovic VM, Spitzner M, Soria RB, Schreiber R. Calcium-dependent chloride conductance in epithelia: is there a contribution by Bestrophin? Pflugers Arch 2007; 454: 879-89.

58 Petrukhin K, Koisti MJ, Bakall B, Li W, Xie G, Marknell T, et al. Identification of the gene responsible for Best macular dystrophy. Nat Genet 1998; 19: 241-7.

59 Xiao Q, Prussia A, Yu K, Cui YY, Hartzell HC. Regulation of bestrophin $\mathrm{Cl}$ channels by calcium: role of the C terminus. J Gen Physiol 2008; 132: 681-92.

60 Schmidt KG, Bergert H, Funk RH. Neurodegenerative diseases of the retina and potential for protection and recovery. Curr Neuropharmacol 2008; 6: 164-78.

61 Kahle JJ, Gulbahce N, Shaw CA, Lim J, Hill DE, Barabasi AL, et al. Comparison of an expanded ataxia interactome with patient medical records reveals a relationship between macular degeneration and ataxia. Hum Mol Genet 2011; 20: 510-27.

$62 \mathrm{Li} \mathrm{GY,} \mathrm{Fan} \mathrm{B,} \mathrm{Zheng} \mathrm{YC.} \mathrm{Calcium} \mathrm{overload} \mathrm{is} \mathrm{a} \mathrm{critical} \mathrm{step} \mathrm{in} \mathrm{pro-}$ grammed necrosis of ARPE-19 cells induced by high-concentration HO. Biomed Environ Sci 2010; 23: 371-7.

63 Marmorstein AD, Marmorstein LY, Rayborn M, Wang X, Hollyfield JG, Petrukhin K. Bestrophin, the product of the Best vitelliform macular dystrophy gene (VMD2), localizes to the basolateral plasma membrane of the retinal pigment epithelium. Proc Natl Acad Sci U S A 2000; 97: 12758-63.

64 Yu K, Xiao Q, Cui G, Lee A, Hartzell HC. The best disease-linked $\mathrm{Cl}^{-}$channel hBest1 regulates Ca $\vee 1$ (L-type) $\mathrm{Ca}^{2+}$ channels via srchomology-binding domains. J Neurosci 2008; 28: 5660-70.

65 Reichhart N, Milenkovic VM, Halsband CA, Cordeiro S, Strauss 0. Effect of bestrophin-1 on L-type $\mathrm{Ca}^{2+}$ channel activity depends on the $\mathrm{Ca}^{2+}$ channel beta-subunit. Exp Eye Res 2010; 91: 630-9.

66 Oliveria SF, Dell'Acqua ML, Sather WA. AKAP79/150 anchoring of calcineurin controls neuronal L-type $\mathrm{Ca}^{2+}$ channel activity and nuclear signaling. Neuron 2007; 55: 261-75.

67 Yatani A, Honda R, Tymitz KM, Lalli MJ, Molkentin JD. Enhanced $\mathrm{Ca}^{2+}$ channel currents in cardiac hypertrophy induced by activation of calcineurin-dependent pathway. J Mol Cell Cardiol 2001; 33: 249-59.

68 Norris CM, Blalock EM, Chen KC, Porter NM, Landfield PW. Calcineurin enhances L-type $\mathrm{Ca}^{2+}$ channel activity in hippocampal neurons: increased effect with age in culture. Neuroscience 2002; 110: 213-25.

69 Norris CM, Blalock EM, Chen KC, Porter NM, Thibault O, Kraner SD, et al. Hippocampal 'zipper' slice studies reveal a necessary role for calcineurin in the increased activity of L-type $\mathrm{Ca}^{2+}$ channels with aging. Neurobiol Aging 2010; 31: 328-38.

70 Bueno OF, van RE, Molkentin JD, Doevendans PA, De Windt LJ. Calcineurin and hypertrophic heart disease: novel insights and remaining questions. Cardiovasc Res 2002; 53: 806-21.

71 Wilkins BJ, Dai YS, Bueno OF, Parsons SA, Xu J, Plank DM, et al. Calcineurin/NFAT coupling participates in pathological but not physiological cardiac hypertrophy. Circ Res 2004; 94: 110-8.

72 Moosmang S, Schulla V, Welling A, Feil R, Feil S, Wegener JW, et al. Dominant role of smooth muscle L-type calcium channel Cav1.2 for blood pressure regulation. EMBO J 2003; 22: 6027-34.

73 Gao T, Cuadra AE, Ma H, Bunemann M, Gerhardstein BL, Cheng T, et al. C-terminal fragments of the alpha $1 \mathrm{C}$ (CaV1.2) subunit associate with and regulate L-type calcium channels containing $\mathrm{C}$-terminal- truncated alpha 1C subunits. J Biol Chem 2001; 276: 21089-97.

74 Emrick MA, Sadilek M, Konoki K, Catterall WA. Beta-adrenergicregulated phosphorylation of the skeletal muscle $\mathrm{Ca}(\mathrm{V}) 1.1$ channel in the fight-or-flight response. Proc Natl Acad Sci U S A 2010; 107: 18712-7.

75 Heineke J, Uger-Messier M, Correll RN, Xu J, Benard MJ, Yuan W, et al. CIB1 is a regulator of pathological cardiac hypertrophy. Nat Med 2010; 16: 872-9.

76 Tandan S, Wang Y, Wang TT, Jiang N, Hall DD, Hell JW, et al. Physical and functional interaction between calcineurin and the cardiac L-type $\mathrm{Ca}^{2+}$ channel. Circ Res 2009; 105: 51-60.

77 Brunet S, Scheuer T, Klevit R, Catterall WA. Modulation of CaV1.2 channels by $\mathrm{Mg}^{2+}$ acting at an EF-hand motif in the $\mathrm{COOH}$-terminal domain. J Gen Physiol 2005; 126: 311-23.

78 McCully JD, Levitsky S. Mechanisms of in vitro cardioprotective action of magnesium on the aging myocardium. Magnes Res 1997; 10: 157-68.

79 Zeilhofer HU, Blank NM, Neuhuber WL, Swandulla D. Calciumdependent inactivation of neuronal calcium channel currents is independent of calcineurin. Neuroscience 2000; 95: 235-41.

80 Christie-Fougere MM, rby-King A, Harley CW, McLean JH. Calcineurin inhibition eliminates the normal inverted $U$ curve enhances acquisition and prolongs memory in a mammalian $3^{\prime}, 5^{\prime}$-cyclic AMP-dependent learning paradigm. Neuroscience 2009; 158: 1277-83.

81 Foster TC, Sharrow KM, Masse JR, Norris CM, Kumar A. Calcineurin links $\mathrm{Ca}^{2+}$ dysregulation with brain aging. J Neurosci 2001; 21 : 4066-73.

82 Tallant EA, Brumley LM, Wallace RW. Activation of a calmodulindependent phosphatase by a $\mathrm{Ca}^{2+}$-dependent protease. Biochemistry 1988; 27: 2205-11.

83 Liu F, Grundke-lqbal I, Iqbal K, Oda Y, Tomizawa K, Gong CX. Truncation and activation of calcineurin $A$ by calpain I in Alzheimer disease brain. J Biol Chem 2005; 280: 37755-62.

84 Wang HG, Pathan N, Ethell IM, Krajewski S, Yamaguchi Y, Shibasaki F, et al. $\mathrm{Ca}^{2+}$-induced apoptosis through calcineurin dephosphorylation of BAD. Science 1999; 284: 339-43.

85 Agostinho P, Lopes JP, Velez Z, Oliveira CR. Overactivation of calcineurin induced by amyloid-beta and prion proteins. Neurochem Int 2008; 52: 1226-33.

86 Brackmann M, Schuchmann S, Anand R, Braunewell KH. Neuronal $\mathrm{Ca}^{2+}$ sensor protein VILIP-1 affects cGMP signalling of guanylyl cyclase $\mathrm{B}$ by regulating clathrin-dependent receptor recycling in hippocampal neurons. J Cell Sci 2005; 118: 2495-505.

87 Ames JB, Ishima R, Tanaka T, Gordon JI, Stryer L, Ikura M. Molecular mechanics of calcium-myristoyl switches. Nature 1997; 389: 198202.

88 Pongs O, Lindemeier J, Zhu XR, Theil T, Engelkamp D, Krah-Jentgens I, et al. Frequenin - a novel calcium-binding protein that modulates synaptic efficacy in the Drosophila nervous system. Neuron 1993; 11: $15-28$

89 Cox JA, Durussel I, Comte M, Nef S, Nef P, Lenz SE, et al. Cation binding and conformational changes in VILIP and NCS-1 two neuronspecific calcium-binding proteins. J Biol Chem 1994; 269: $32807-$ 13.

90 Tsujimoto T, Jeromin A, Saitoh N, Roder JC, Takahashi T. Neuronal calcium sensor 1 and activity-dependent facilitation of $\mathrm{P} / \mathrm{Q}$-type calcium currents at presynaptic nerve terminals. Science 2002; 295: 2276-9.

91 Jinno S, Jeromin A, Roder J, Kosaka T. Immunocytochemical localization of neuronal calcium sensor-1 in the hippocampus and cerebellum of the mouse with special reference to presynaptic terminals. 
Neuroscience 2002; 113: 449-61.

92 Blasiole B, Kabbani N, Boehmler W, Thisse B, Thisse C, Canfield V, et al. Neuronal calcium sensor-1 gene ncs-1a is essential for semicircular canal formation in zebrafish inner ear. J Neurobiol 2005; 64: 285-97.

93 Reynolds AJ, Bartlett SE, Morgans C. The distribution of neuronal calcium sensor-1 protein in the developing and adult rat retina. Neuroreport 2001; 12: 725-8.

94 Bergmann M, Grabs D, Roder J, Rager G, Jeromin A. Differential expression of neuronal calcium sensor-1 in the developing chick retina. J Comp Neurol 2002; 449: 231-40.

95 Genin A, Davis S, Meziane H, Doyere V, Jeromin A, Roder J, et al. Regulated expression of the neuronal calcium sensor-1 gene during long-term potentiation in the dentate gyrus in vivo. Neuroscience 2001; 106: 571-7.

96 Rivosecchi R, Pongs O, Theil T, Mallart A. Implication of frequenin in the facilitation of transmitter release in Drosophila. J Physiol 1994; 474: 223-32.

97 Jeromin A, Shayan AJ, Msghina M, Roder J, Atwood HL. Crustacean frequenins: molecular cloning and differential localization at neuromuscular junctions. J Neurobiol 1999; 41: 165-75.

98 Dason JS, Romero-Pozuelo J, Marin L, lyengar BG, Klose MK, Ferrus $\mathrm{A}$, et al. Frequenin/NCS-1 and the $\mathrm{Ca}^{2+}$-channel alpha1-subunit coregulate synaptic transmission and nerve-terminal growth. J Cell Sci 2009; 122: 4109-21.

99 Wang CY, Yang F, He X, Chow A, Du J, Russell JT, et al. C Ca ${ }^{2+}$ binding protein frequenin mediates GDNF-induced potentiation of $\mathrm{Ca}^{2+}$ channels and transmitter release. Neuron 2001; 32: 99-112.

100 Hui K, Fei GH, Saab BJ, Su J, Roder JC, Feng ZP. Neuronal calcium sensor-1 modulation of optimal calcium level for neurite outgrowth. Development 2007; 134: 4479-89.

101 Hui K, Feng ZP. NCS-1 differentially regulates growth cone and somata calcium channels in Lymnaea neurons. Eur J Neurosci 2008; 27: 631-43.

102 Braunewell KH, Klein-Szanto AJ. Visinin-like proteins (VSNLs): interaction partners and emerging functions in signal transduction of a subfamily of neuronal $\mathrm{Ca}^{2+}$-sensor proteins. Cell Tissue Res 2009; 335: 301-16.

103 Braunewell KH, Gundelfinger ED. Intracellular neuronal calcium sensor proteins: a family of EF-hand calcium-binding proteins in search of a function. Cell Tissue Res 1999; 295: 1-12.

104 Lautermilch NJ, Few AP, Scheuer T, Catterall WA. Modulation of
CaV2.1 channels by the neuronal calcium-binding protein visinin-like protein-2. J Neurosci 2005; 25: 7062-70.

105 Few AP, Lautermilch NJ, Westenbroek RE, Scheuer T, Catterall WA. Differential regulation of CaV2.1 channels by calcium-binding protein 1 and visinin-like protein-2 requires $\mathrm{N}$-terminal myristoylation. J Neurosci 2005; 25: 7071-80.

106 Gonzalez Guerrico AM, Jaffer ZM, Page RE, Braunewell KH, Chernoff J, Klein-Szanto AJ. Visinin-like protein-1 is a potent inhibitor of cell adhesion and migration in squamous carcinoma cells. Oncogene 2005; 24: 2307-16.

107 Fu J, Jin F, Zhang J, Fong K, Bassi DE, Lopez De CR, et al. VILIP-1 expression in vivo results in decreased mouse skin keratinocyte proliferation and tumor development. PLoS One 2010; 5: e10196.

108 Buttgereit J, Qadri F, Monti J, Langenickel TH, Dietz R, Braunewell KH, et al. Visinin-like protein 1 regulates natriuretic peptide receptor $B$ in the heart. Regul Pept 2010; 161: 51-7.

109 Palotas A, Kalman J, Palotas M, Juhasz A, Janka Z, Penke B. Fibroblasts and lymphocytes from Alzheimer patients are resistant to betaamyloid-induced increase in the intracellular calcium concentration. Prog Neuropsychopharmacol Biol Psychiatry 2002; 26: 971-4.

110 Saito K, Elce JS, Hamos JE, Nixon RA. Widespread activation of calcium-activated neutral proteinase (calpain) in the brain in Alzheimer disease: a potential molecular basis for neuronal degeneration. Proc Natl Acad Sci U S A 1993; 90: 2628-32.

111 Nixon RA, Saito KI, Grynspan F, Griffin WR, Katayama S, Honda T, et al. Calcium-activated neutral proteinase (calpain) system in aging and Alzheimer's disease. Ann N Y Acad Sci 1994; 747: 77-91.

112 Spillantini MG, Schmidt ML, Lee VM, Trojanowski JQ, Jakes R, Goedert M. Alpha-synuclein in Lewy bodies. Nature 1997; 388: 839-40.

113 Polymeropoulos MH, Lavedan C, Leroy E, Ide SE, Dehejia A, Dutra A, et al. Mutation in the alpha-synuclein gene identified in families with Parkinson's disease. Science 1997; 276: 2045-7.

114 Martinez J, Moeller I, Erdjument-Bromage H, Tempst P, Lauring B. Parkinson's disease-associated alpha-synuclein is a calmodulin substrate. J Biol Chem 2003; 278: 17379-87.

115 Ubeda-Banon I, Saiz-Sanchez D, de la Rosa-Prieto C, ArgandonaPalacios L, Garcia-Munozguren S, Martinez-Marcos A. alphaSynucleinopathy in the human olfactory system in Parkinson's disease: involvement of calcium-binding protein- and substance P-positive cells. Acta Neuropathol 2010; 119: 723-35. 